\title{
IDENTIFIKASI FOTO WANITA BERHIJAB DARI MAJALAH UNTUK PEMBUATAN KATALOG BUSANA MUSLIM OTOMATIS MEMANFAATKAN CONVOLUTIONAL NEURAL NETWORK
}

\author{
M. Najamudin Ridha, STMIK Indonesia Banjarmasin, Endang Setyati, Institut Sains dan Teknologi \\ Terpadu Surabaya, Yosi Kristian, Institut Sains dan Teknologi Terpadu Surabaya
}

\begin{abstract}
Abstrak-Perkembangan Fashion Muslim di Indonesia terus meningkat, disisi lain terobosan baru pada Deep Learning dengan memadukan arsitektur seperti dropout regularizations dan Rectified Linear Unit (ReLU) sebagai fungsi aktivasi dan data augmentation, mampu mencapai terobosan pada large scale image classification. Penelitian ini menggunakan metode deteksi objek wajah dengan Haar Cascades Classification untuk mendapatkan sample dataset wajah dan preprocessing data testing untuk dilanjutkan pada metode machine learning untuk klasifikasi citra dengan Convolutional Neural Network. Dataset yang digunakan adalah kumpulan katalog busana online, dataset yang sudah di preprocessing dibagi menjadi dua kategori, yaitu Hijab untuk semua citra wanita berhijab, dan Non Hijab untuk citra yang bukan wanita berhijab. selanjutnya klasifikasi citra menggunakan data ujicoba majalah digital terbitan Hijabella, Joy Indonesia dan Scarf Indonesia. Semakin besar resolusi citra input untuk preprocessing pada majalah digital, maka akan semakin banyak objek citra yang terdeteksi, dengan meningkatkan jumlah dataset untuk training dan validasi, mampu menambah hasil akurasi yang didapatkan, terjadi peningkatan akurasi pada dataset 2.500 wajah perkategori ke 5.000 wajah perkategori dengan resolusi 720p meningkat dari rata-rata $81.30 \%$ menjadi $82.31 \%$, peningkatan rata-rata $1.01 \%$ dan tertinggi $2.14 \%$, sedangkan resolusi $1080 \mathrm{p}$ meningkat dari rata-rata $83.03 \%$ menjadi $83.68 \%$, peningkatan rata-rata $0.65 \%$ dan tertinggi $1.73 \%$, akurasi tertinggi adalah sebesar $84.72 \%$ menggunakan model dataset 5.000 secara acak perkategori.
\end{abstract}

Kata Kunci-Fashion Muslim, Majalah Digital, Katalog Online, Hijab, Haar Cascades Classification, Convolutional Neural Network

\section{Pendahuluan}

$\mathrm{P}$ erkembangan fashion muslim di Indonesia terus meningkat, sebagian besar didorong oleh banyaknya perancang busana muslim dan suksesnya proses transformasi dari gaya konservatif menjadi lebih kontemporer yang sesuai dengan tipikal generasi muda Indonesia, ada beberapa faktor lain yang mendorong perkembangan tren fashion, mulai dari munculnya banyak komunitas seperti Hijabers Community, Hijabers Mom, sampai diselenggarakannya beragam bazar dan peragaan busana muslim

M. Najamudin Ridha, Sekolah Tinggi Manajemen Informatika dan Komputer Indonesia Banjarmasin, Banjarmasin, Kalimantan Selatan, Indonesia (e-mail:admin@komptuterkampus.com)

Endang Setyati, Magister Teknologi Informasi, Institut Sains dan Teknologi Terpadu Surabaya, Surabaya, Jawa Timur, Indonesia(email:endang@stts.edu)

Yosi Kristian, Magister Teknologi Informasi, Institus Sains dan Teknologi Terpadu Surabaya, Surabaya, Jawa Timur, Indonesia(email:yosi@stts.edu)
Menurut Dirjen Industri Kecil Menengah (IKM) Kementrian Perindustrian, pada tahun 2015 terdapat 20 Juta penduduk indonesia yang menggunakan hijab, hal ini selaras dengan perkembangan industri fashion muslim sebesar 7 persen setiap tahun. Peran pemerintah dalam mendukung trend fashion muslim sebagai icon fashion Indonesia di mata dunia dengan berbagai usaha yang mendukung para penggiat fashion Indonesia baik berupa bahan baku, teknologi, SDM, pemasaran dan modal.

Dalam dunia Internet, persebaran tren fashion bahkan lebih cepat dari media massa, ada banyak sekali model fashion dari berbagai sumber dan merek. Jenis dan gaya yang tak terbatas. Para pengusaha yang bergerak dibidang fashion saling berlomba-lomba dalam memasarkan produk yang dibuat, banyak katalog dan majalah yang membahas masalah fashion muslim, baik hijab, dress dan lain sebagainya. Untuk membuat katalog secara otomatis diperlukan cara yang dapat memisah fashion tertentu dari kumpulan jenis dan gaya fashion yang ada sesuai dengan kategorinya dengan memanfaatkan Computer Vision dalam proses pengkategorian.

Salah satu kekurangan pada bidang citra digital adalah untuk mengenali object yang ada pada citra secara umum, berbagai kalangan diseluruh dunia mencoba melakukan pendekatan pengenalan citra bagi komputer agar dapat meniru kemampuan manusia dalam mengenali object. Salah satu pendekatan yang berhasil digunakan adalah Neural Network yang terinspirasi dari jaringan syaraf pada manusia. Konsep ini kemudian dikembangkan lebih lanjut dalam Deep Learning.[1].

Banyak metode yang bisa digunakan untuk klasifikasi manusia berdasarkan gaya, raut wajah, pakaian yang digunakan, dan lain sebagainya, saat ini teknik Machine Learning menghasilkan hasil yang sangat bagus untuk mengatasi masalah klasifikasi Machine Learning yang lebih advance, salah satunya adalah Deep Convolutional Neural Network (CNN) yang merupakan metode Deep Learning yang powerful[2]. Namun CNN, seperti metode Deep Learning lainnya, memiliki kelemahan yaitu proses pelatihan model yang lama. Dengan perkembangan perangkat keras, hal tersebut dapat diatasi menggunakan teknologi General Purpose Graphical Processing Unit (GPGPU).

Metode CNN bukanlah ilmu baru, perkembangan awal dari rancangan (Fukushima, 1980) sebuah unsupervised artificial networks dengan nama Neocognitron yang terinspirasi dari system visual biologis rancangan Hubel dan Wiesel. Namun diakhir tahun 1990-an hingga tahun 2000-an, Neural Network 
hampir dilupakan karena muncul berbagai algoritma seperti Support Vector Machines, AdaBoost dan lainnya yang dapat dieksekusi lebih cepat dan dengan performa yang lebih baik pada waktu itu, Neural Network kembali mendapatkan perhatian ketika Deep Belief Network (Hinton, 2006) membuat terobosan dengan menjadi model Handwritten Digit Recognition paling akurat yang akhirnya muncul istilah Deep Learning.[3].

Pada tahun 2012 muncul terobosan baru pada deep learning dengan memadukan arsitektur seperti drop out regularizations dan Rectified Linear Unit (ReLU) sebagai fungsi aktivasi dan data augmentation, mampu mencapat terobosan pada large scale image classification (ImageNet) yang memiliki 1000 kategori citra dari 1,2 juta citra melebihi dari performa manusia. model ini dikenal dengan nama AlexNet, proses trainingnya hanya menggunakan 1 fase saja, yaitu supervised backpropagation, sehingga menyebabkan banyak orang tidak percara lagi pengaruh dari fase unsupervised pre-training[3].

\section{HAAR CASCADES ClASSIFIER}

Haar like feature atau dikenal sebagai Haar Cascades Classifier merupakan rectangular (persegi) feature, yang memberikan indikasi secara spesifik pada citra, Haar Cascade Classifier berasal dari gagasan Paul Viola dan Michael Jhon, karena itu dinamakan metode Viola \& Jhon, ide dari Haar like feature adalah mengenali objek berdasarkan nilai sederhana dari fitur tetapi bukan merupakan nilai piksel dari image object tersebut. Metode ini memiliki kelebihan komputasi yang sangat cepat, karena hanya tergantung pada jumlah piksel dalam persegi bukan setiap nilai piksel dari sebuah image. Pendekatan untuk mendeteksi objek dalam gambar menggabungkan empat kunci utama, yaitu haar like feature, integral image, adaboost learning dan cascade classifier[9].

Haar Feature adalah fitur yang didasarkan pada Wavelet Haar, yaitu gelombang tunggal bujur sangkar (satu interval tinggi dan satu interval rendah). Untuk dua dimensi, satu terang dan satu gelap, selanjutnya kombinasi-kombinasi kotak yang digunakan untuk pendeteksian objek visual yang lebih baik. Setiap haar-like feature terdiri dari gabungan kotak - kotak hitam dan putih, seperti pada persamaan .

\section{$f(x)=$ SumBlack rectangle-SumWhite rectangel}

Fitur Haar ditentukan dengan cara mengurangi rata-rata piksel pada daerah gelap dari rata-rata piksel pada daerah terang, jika nilai perbedaaanya itu diatas nilai threshold, maka dapat dikatakan bahwa fitur tersebut. Nilai dari haar-like feature adalah perbedaan antara jumlah nilai-nilai piksel gray level dalam daerah kotak hitam dan daerah kotak putih. Dimana kotak putih pada haar-like feature dapat dihitung secara cepat menggunakan integral image.

\section{Convolutional Neural Network}

Convolutional Neural Network adalah salah satu metode machine learning dari pengembangan Multi Layer Perceptron (MLP) yang didesain untuk mengolah data dua dimensi. Convolutional Neural Network termasuk dalam jenis Deep Neural Network karena dalamnya tingkat jaringan dan banyak diimplementasikan dalam data citra. Convolutional Neural Network memiliki dua metode; yakni klasifikasi menggunakan feedforward dan tahap pembelajaran menggunakan backpropagation. Cara kerja Convolutional Neural Network memiliki kesamaan pada Multi Layer Perceptron, namun dalam Convolutional Neural Network setiap neuron dipresentasikan dalam bentuk dua dimensi, tidak seperti Multi Layer Perceptron yang setiap neuron hanya berukuran satu dimensi.

\section{IDENTIFIKASI WANITA BERHIJAB}

Data input sebagai training adalah kumpulan wajah yang berhijab dan tidak berhijab, untuk data training dikumpulkan dari data katalog busana online yang diambil dari beberapa katalog busana online dan website busana muslim.

Alur sistem pada blok sistem gambar 1 dimana pada data preprosessing untuk mengumpulkan data training dan validasi dari kumpulan katalog online adalah menggunakan metode Haar Cascades Clasification untuk deteksi wajah secara frontal. Setiap wajah yang ditemukan, baik berhijab atau tidak, maka akan diklasifikasi dengan kategori Hijab dan Non hijab, yang kemudian akan diteruskan ke metode Convolutional Neural Network model Alexnet untuk training, hasil model dari training akan disimpan untuk transfer learning dan digunakan kembali untuk klasifikasi foto wajah yang ditemukan Haar Cascades Classification untuk idenfitikasi wajah berhijab atau non hijab.

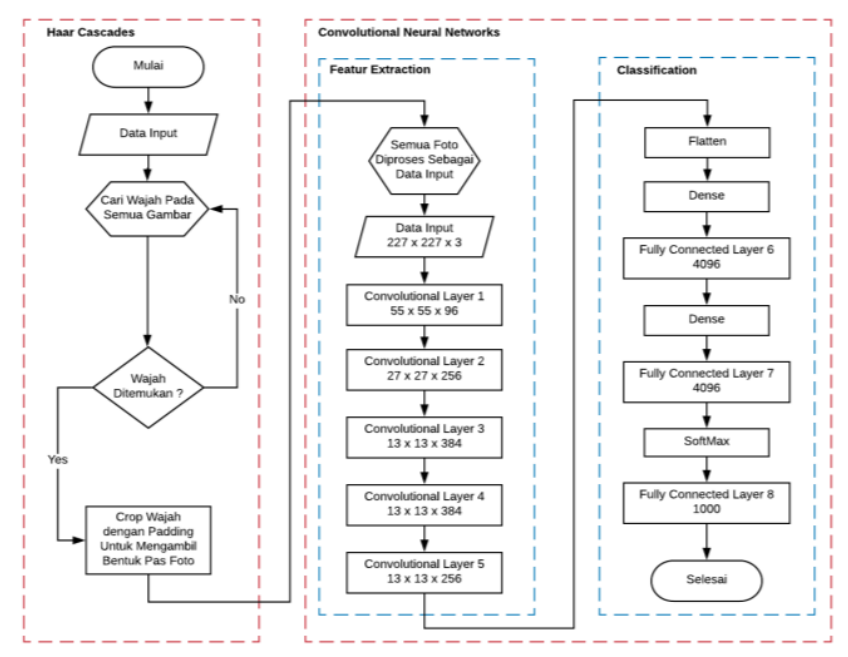

Gambar. 1. Blok Diagram Arsitektur Sistem

\section{A. Data Input dan Data Output}

Data input sebagai testing / ujicoba adalah Majalah digital pada aplikasi Gramedia, dengan mengambil ScreenShoot tiap halaman dan kemudian dikonversi kebentuk PDF, majalah yang akan digunakan adalah majalah terbitan Hijabella, Joy Indonesia dan Scarf Indonesia sebagai perbandingan hasil tiap majalah. Informasi terbitan dan jumlah halaman dapat dilihat pada tabel I.

Data input sebagai training adalah kumpulan wajah yang berhijab dan tidak berhijab, untuk data training dikumpulkan dari data katalog busana online yang diambil dari beberapa katalog online dan website busana muslim. Data katalog terdapat pada table II. 
TABEL I

MAJALAH DigitAL UNTUK DATA TESTING

\begin{tabular}{|c|l|l|l|}
\hline No & \multicolumn{1}{|c|}{ Majalah } & \multicolumn{1}{c|}{ Edisi } & Jumlah \\
\hline 1 & Hijabella & 16, 30 Nov 2014 & $132 \mathrm{Hal}$ \\
\hline 2 & Hijabella & 17, 07 Jan 2015 & $132 \mathrm{Hal}$ \\
\hline 3 & Hijabella & $18,11 \mathrm{Mar} 2015$ & $132 \mathrm{Hal}$ \\
\hline 4 & Joy Indonesia & Okt 2016 & $148 \mathrm{Hal}$ \\
\hline 5 & Joy Indonesia & Nov 2016 & $148 \mathrm{Hal}$ \\
\hline 6 & Joy Indonesia & Des 2016 & $148 \mathrm{Hal}$ \\
\hline 7 & Scarf Indonesia & 31 Jan 2017 & $120 \mathrm{Hal}$ \\
\hline 8 & Scarf Indonesia & 21 Des 2017 & $120 \mathrm{Hal}$ \\
\hline 9 & Scarf Indonesia & 22 Jan 2018 & $120 \mathrm{Hal}$ \\
\hline
\end{tabular}

Informasi terbitan dan jumlah halaman pada majalah digital

TABEL II

KATALOG DIGITAL UNTUK DATA TRAINING

\begin{tabular}{|c|c|c|}
\hline No & Katalog/Website & Tahun \\
\hline 1 & Katalog Azzura & Terbitan 2017 \\
\hline 2 & Katalog Munira & Terbitan 2018 \\
\hline 3 & Katalog Garsel Fashion & Terbitan $2017-2018$ \\
\hline 4 & Katalog Gareu Fashion & Terbitan $2017-2018$ \\
\hline 5 & Katalog Garucci & Terbitan $2017-2018$ \\
\hline 6 & Katalog Guardno & Terbitan $2017-2018$ \\
\hline 7 & Katalog Blackkelly & Terbitan $2017-2018$ \\
\hline 8 & Katalog Inficlo & Terbitan $2017-2018$ \\
\hline 9 & Katalog Catenzo & Terbitan $2017-2018$ \\
\hline 10 & Katalog Golfer & Terbitan $2017-2018$ \\
\hline 11 & Katalog Java Seven & Terbitan $2017-2018$ \\
\hline 12 & Katalog Basama Soga & Terbitan $2017-2018$ \\
\hline 13 & Katalog GShop Geearsy & Terbitan $2017-2018$ \\
\hline 14 & Web Najilla Hijab & Diakses 2018 \\
\hline 15 & Web Miranda Hijab & Diakses 2018 \\
\hline 17 & Web Jenahara & Diakses 2018 \\
\hline 18 & Web Rabbani & Diakses 2018 \\
\hline 19 & Web Jilbab Flow Idea & Diakses 2018 \\
\hline 20 & Web Elzatta & Diakses 2018 \\
\hline 21 & Web Zoya & Diakses 2018 \\
\hline 22 & Web Jenahara & Diakses 2018 \\
\hline
\end{tabular}

Katalog digital yang digunakan untuk data training

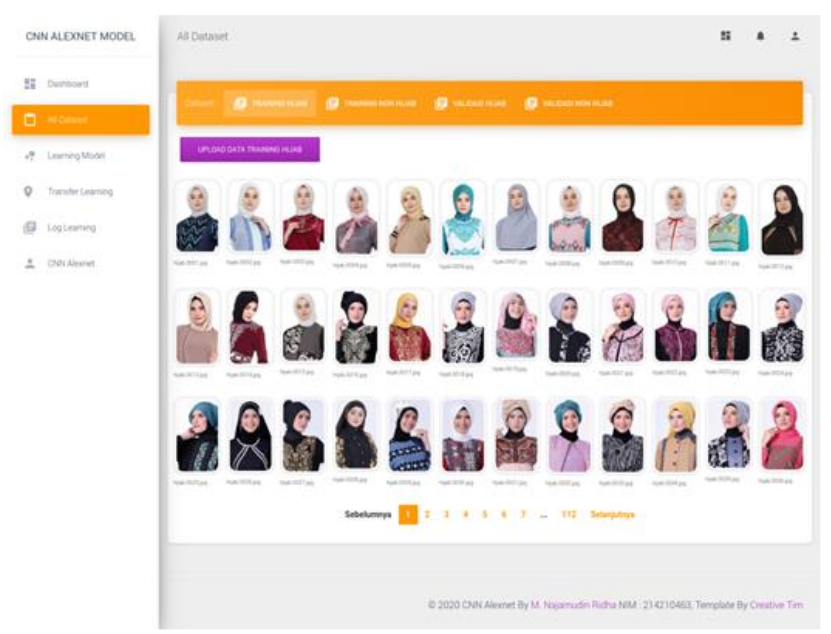

Gambar. 2. Contoh output Face Detection dengan Haar Cascade Classification data Training dari katalog digital

\section{B. Preprocessing Dataset Training}

Proses ekstraksi wajah pada setiap katalog online, menggunakan metode Haar Cascades Classification untuk menemukan wajah dengan memanfaatkan library OpenCV. Seluruh dataset yang akan digunakan untuk proses training dan validasi model Convolutional Neural Network adalah hasil dari face detection secara frontal dengan metode Haar Cascades Classification, output proses preprocessing seperti pada gambar 2 .

Setelah wajah ditemukan, untuk data training dan validasi, dilakukan pengelompokan citra dengan kategori "Hijab" dan "Nonhijab". Rincian pengelompokan dataset pada tabel III.

TABEL III

RINCIAN DATASET YANG DIKUMPULKAN PERKATEGORI

\begin{tabular}{|l|l|l|l|l|l|}
\hline \multirow{2}{*}{ No } & \multirow{2}{*}{ Dataset } & Ket & Hijab & Non & Total \\
\hline 1 & 2.500 & Training & 2.000 & 2.000 & 4.000 \\
\cline { 3 - 6 } & & Validasi & 500 & 500 & 1.000 \\
\hline 2 & \multirow{2}{*}{5.000} & Training & 4.000 & 4.000 & 8.000 \\
\cline { 3 - 6 } & & Validasi & 1.000 & 1.000 & 2.000 \\
\hline 3 & 2.500 & Training & 2.000 & 2.000 & 4.000 \\
\cline { 3 - 6 } & Acak & Validasi & 500 & 500 & 1.000 \\
\hline 4 & 5.000 & Training & 4.000 & 4.000 & 8.000 \\
\cline { 3 - 6 } & Acak & Validasi & 1.000 & 1.000 & 2.000 \\
\hline
\end{tabular}

Katalog digital yang digunakan dibagi menjadi 4 kelompok.

Proses ekstraksi wajah pada majalah digital menggunakan program yang sama dengan ekstraksi wajah pada data training, yaitu menggunakan Haar Cascades Classification, perbandingan hasil ekstraksi wajah dengan resolusi berbeda dapat dilihat pada table IV.

TABEL IV

PERBANDINGAN HASIL EKSTRAKSI WAJAH DENGAN RESOLUSi BERBEDA

\begin{tabular}{|c|l|l|c|c|}
\hline \multirow{2}{*}{ No } & \multicolumn{1}{|c|}{ Majalah } & Hal & \multicolumn{2}{|c|}{ Wajah Ditemukan } \\
\cline { 4 - 5 } & & \multicolumn{1}{|c|}{$\mathbf{7 2 0 p}$} & $\mathbf{1 0 8 0 p}$ \\
\hline 2 & $\begin{array}{l}\text { Hijabella Ed.16, } \\
\text { 30 Nov 2014 }\end{array}$ & 132 & 166 & 233 \\
\hline 2 & $\begin{array}{l}\text { Hijabella Ed.17, } \\
\text { 07 Jan 2015 }\end{array}$ & 132 & 188 & 267 \\
\hline 3 & $\begin{array}{l}\text { Hijabella Ed.18, } \\
11 \text { Mar2015 }\end{array}$ & 132 & 170 & 216 \\
\hline 4 & $\begin{array}{l}\text { Joy Indonesia } \\
\text { Ed.Okt 2016 }\end{array}$ & 148 & 228 & 281 \\
\hline 5 & $\begin{array}{l}\text { Joy Indonesia } \\
\text { Ed.Nov 2016 }\end{array}$ & 148 & 223 & 274 \\
\hline 6 & $\begin{array}{l}\text { Joy Indonesia } \\
\text { Ed.Des 2016 }\end{array}$ & 148 & 291 & 351 \\
\hline 7 & $\begin{array}{l}\text { Scarf Indonesia } \\
\text { Ed.31 Jan 2017 }\end{array}$ & 120 & 137 & 251 \\
\hline 8 & $\begin{array}{l}\text { Scarf Indonesia } \\
\text { Ed.21 Des 2017 }\end{array}$ & 120 & 121 & 179 \\
\hline 9 & $\begin{array}{l}\text { Scarf Indonesia } \\
\text { Ed.22 Jan 2018 }\end{array}$ & 120 & 111 & 161 \\
\hline
\end{tabular}

Resolusi 720p menggunakan perangkat Samsung Galaxy A6, sedangkan resolusi 1080p menggunakan perangkat Xiaomi Redmi Note 7.

Dari data table IV, dapat dilihat dengan semakin besar resolusi citra sebuah majalah digital, semakin banyak wajah 
yang ditemukan dengan metode Haar Cascades Classification, Grafik perbandingan hasil ekstraksi wajah dari majalah dapat dilihat pada gambar 3 .

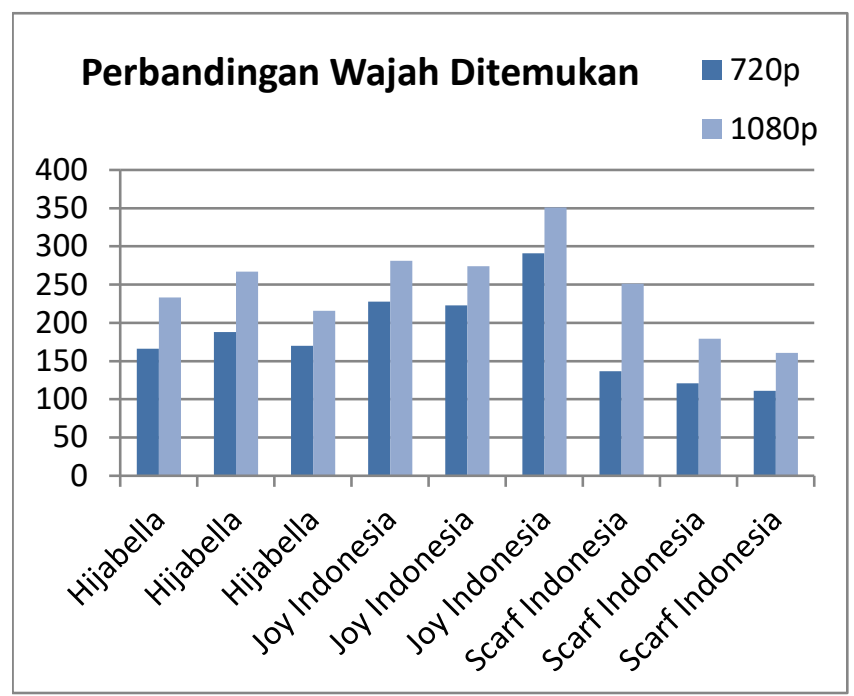

Gambar. 3. Grafik Perbandingan Wajah Ditemukan Berdasarkan Resolusi

\section{Training Model Convolutional Neural Network}

Dataset yang akan digunakan untuk training model Convolutional Neural Network adalah dataset training yang didapatkan dari ekstraksi wajah katalog digital pada tabel 3.2 untuk data training. Arsitektur model yang digunakan adalah AlexNet pada gambar 4 .

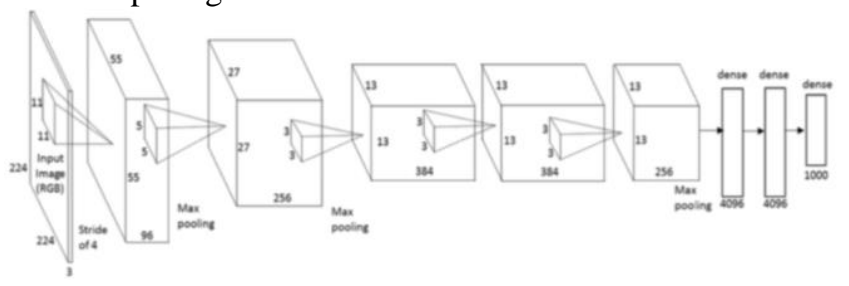

Gambar. 4. Arsitektur Model Alexnet[17]

Proses training dataset menggunakan beberapa model sesuai dengan kategori pada table III. Kemudian akan dilakukan ujicoba model training terhadap majalah digital.

\section{Evaluasi Data Testing}

Pada bagian preprocessing data testing di tabel IV terdapat perbandingan hasil ekstraksi wajah dengan resolusi berbeda, terbukti bahwa metode Haar Cascades Classification mampu mendeteksi lebih banyak wajah dengan resolusi yang semakin tinggi, untuk menghitung tingkat akurasi modelmodel yang sudah di training dengan model Convolutional Neural Network, diperlukan uji coba dengan data-data berupa majalah - majalah digital, proses perhitungan akurasi model yang sudah di transfer learning dapat melakukan model Evaluate antara data Testing dengan model yang sudah ada, namun perlu memisahkan hasil ekstraksi wajah dengan Haar Cascades Classification pada majalah digital antara wajah berhijab dan tidak berhijab menyesuaikan model Convolutional Neural Network. Pengaturan parameter untuk training model seperti pada gambar 5 .

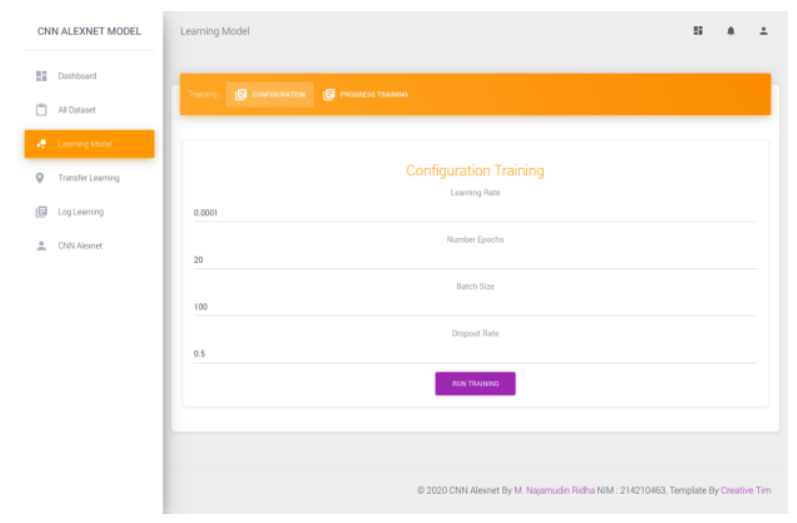

Gambar. 5. Custom Parameter untuk training model

Hasil klasifikasi data wajah akan digunakan untuk testing evaluasi model-model yang sudah di training, pada data training dengan berbagai parameter, data parameter dapat dilihat pada table $\mathrm{V}$.

TABEL V

DATA PARAMETER MODEL TRAINING

\begin{tabular}{|c|c|c|c|c|c|c|}
\hline No & Nama & Learn & $\begin{array}{c}\text { Drop } \\
\text { Out }\end{array}$ & $\begin{array}{c}\text { Batch } \\
\text { Size }\end{array}$ & Epoch & $\begin{array}{c}\text { Early } \\
\text { Stop }\end{array}$ \\
\hline 1 & Test 01 & 0.0001 & 0.4 & $\mathbf{1 0 0}$ & $\mathbf{1 0 0}$ & - \\
\hline 2 & Test 02 & 0.0001 & 0.4 & $\mathbf{2 0 0}$ & $\mathbf{1 0 0}$ & - \\
\hline 3 & Test 03 & 0.0001 & 0.4 & $\mathbf{3 0 0}$ & $\mathbf{1 0 0}$ & - \\
\hline 4 & Test 04 & 0.0001 & 0.4 & $\mathbf{4 0 0}$ & $\mathbf{1 0 0}$ & - \\
\hline 5 & Test 05 & 0.0001 & 0.4 & $\mathbf{5 0 0}$ & $\mathbf{1 0 0}$ & - \\
\hline 6 & Test 06 & 0.0001 & 0.5 & $\mathbf{1 0 0}$ & $\mathbf{1 0 0}$ & - \\
\hline 7 & Test 07 & 0.0001 & 0.5 & $\mathbf{2 0 0}$ & $\mathbf{1 0 0}$ & - \\
\hline 8 & Test 08 & 0.0001 & 0.5 & $\mathbf{3 0 0}$ & $\mathbf{1 0 0}$ & - \\
\hline 9 & Test 09 & 0.0001 & 0.5 & $\mathbf{4 0 0}$ & $\mathbf{1 0 0}$ & - \\
\hline 10 & Test 10 & 0.0001 & 0.5 & $\mathbf{5 0 0}$ & $\mathbf{1 0 0}$ & - \\
\hline 11 & Test 11 & 0.0001 & 0.4 & $\mathbf{1 0 0}$ & - & $\mathbf{2 5}$ \\
\hline 12 & Test 12 & 0.0001 & 0.4 & $\mathbf{2 0 0}$ & - & $\mathbf{2 5}$ \\
\hline 13 & Test 13 & 0.0001 & 0.4 & $\mathbf{3 0 0}$ & - & $\mathbf{2 5}$ \\
\hline 14 & Test 14 & 0.0001 & 0.4 & $\mathbf{4 0 0}$ & - & $\mathbf{2 5}$ \\
\hline 15 & Test 15 & 0.0001 & 0.4 & $\mathbf{5 0 0}$ & - & $\mathbf{2 5}$ \\
\hline 16 & Test 16 & 0.0001 & 0.5 & $\mathbf{1 0 0}$ & - & $\mathbf{2 5}$ \\
\hline 17 & Test 17 & 0.0001 & 0.5 & $\mathbf{2 0 0}$ & - & $\mathbf{2 5}$ \\
\hline 18 & Test 18 & 0.0001 & 0.5 & $\mathbf{3 0 0}$ & - & $\mathbf{2 5}$ \\
\hline 19 & Test 19 & 0.0001 & 0.5 & $\mathbf{4 0 0}$ & - & $\mathbf{2 5}$ \\
\hline 20 & Test 20 & 0.0001 & 0.5 & $\mathbf{5 0 0}$ & - & $\mathbf{2 5}$ \\
\hline
\end{tabular}

Model-model training dengan berbagai parameter

Proses training dataset pada setiap model akan disimpan dan digunakan untuk transfer learning sebagai ujicoba data testing untuk melihat nilai akurasi model yang telah di training, proses training model dapat dilihat pada gambar 6 .

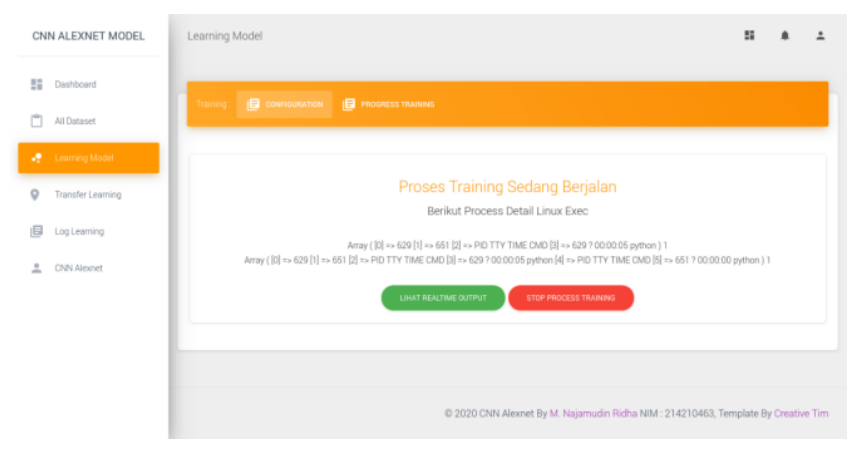

Gambar. 7. Proses Training model dengan Dataset 
Setiap majalah yang akan dilakukan untuk ujicoba pada tablel II akan dievaluasi dengan model-model yang dibuat dengan berbagai parameter seperti pada table $\mathrm{V}$, setiap model menggunakan 4 kelompok kategori data training seperti pada tabel III, model hasil training disimpan dengan format hadoop filesystem h5. Untuk memilih model tertentu seperti pada gambar 7 .

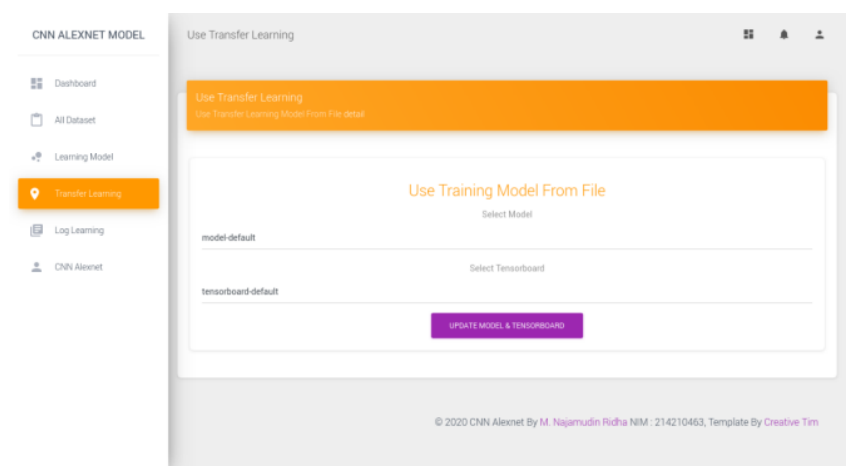

Gambar. 7. Setting Transfer Learning model

Majalah yang diujicoba menggunakan perangkat berbeda dengan resolusi 720p dan 1080p untuk melihat hasil perbandingan perbedaan resolusi terhadap model Convolutional Neural Network yang dibuat. Log proses training dapat dilihat pada gambar 8 .

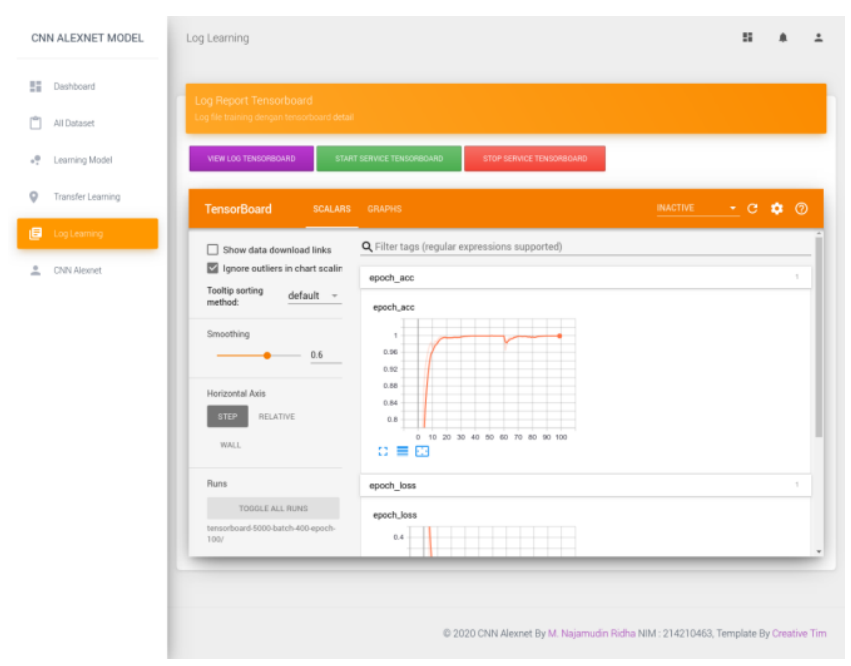

Gambar. 8. Log Proses Training dari Tensorboard

Proses testing data, bisa menggunakan data input berupa file pdf ataupun jpg/jpeg/png, untuk memilih input data testing seperti pada gambar 9 .

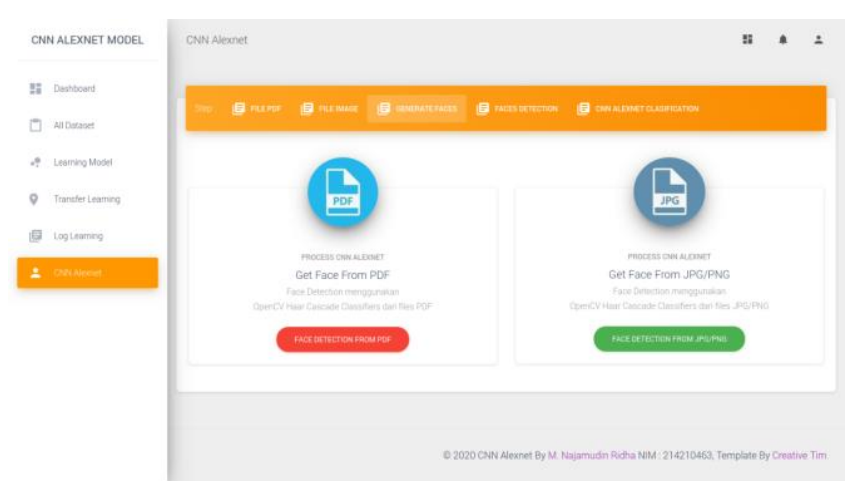

Gambar. 9. Memilih input data Testing
Untuk memudahkan evaluasi data testing, setiap proses klasifikasi dengan Convolutional Neural Network permajalah, contoh 12 halaman pertama majalah Hijabella dari file jpg seperti pada gambar 10 .

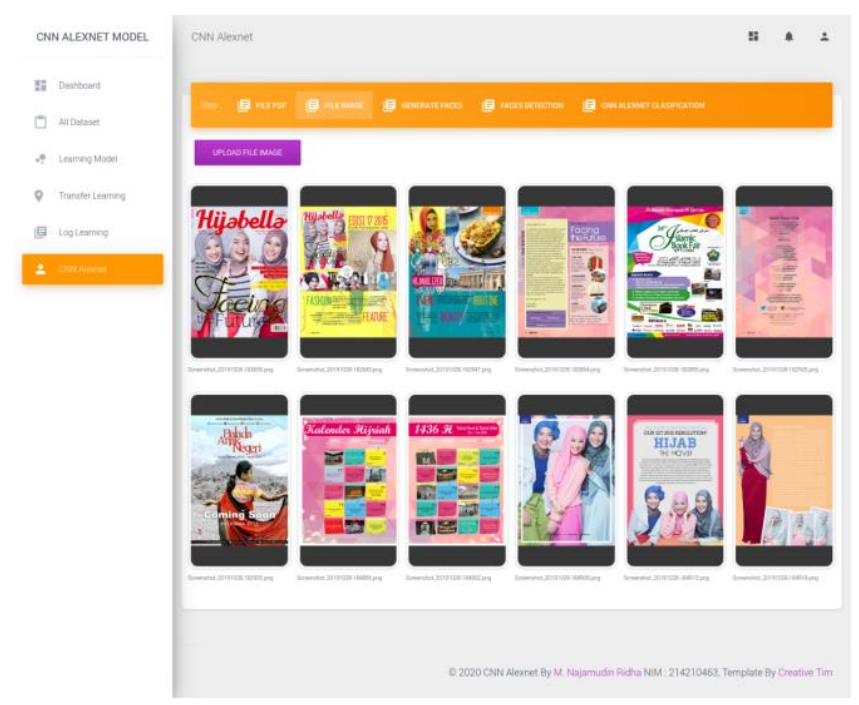

Gambar. 10. Majalah Hijabella untuk Data Testing

Proses Haar Cascade Classification untuk ektraksi wajah yang ditemukan pada majalah untuk input data testing seperti gambar 11 .

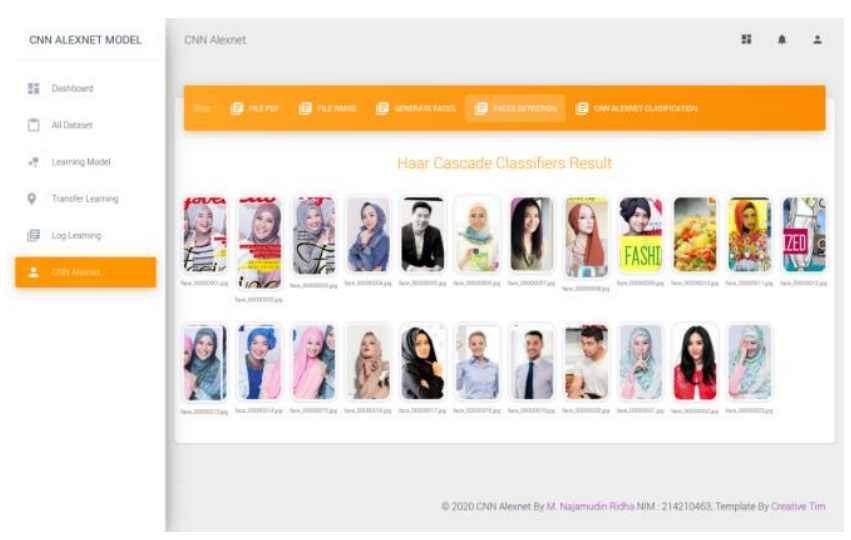

Gambar. 11. Hasil Deteksi Wajah Haar Cascades Classification

Wajah yang berhasil diidentifikasi akan diteruskan ke proses klasifikasi, apakah foto berhijab atau tidak berhijab, proses identifikasi dengan Convolutional Neural Network seperti gambar 12 .

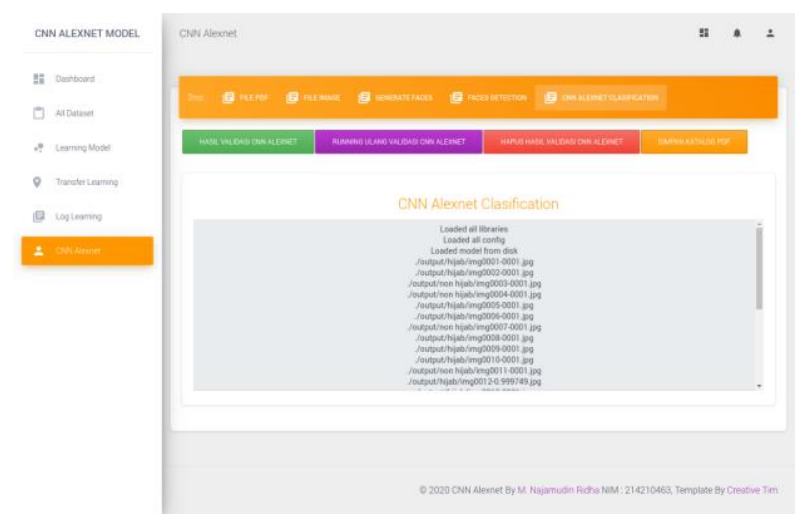

Gambar. 12. Proses identifikasi wajah berhijab dengan Convolutional Neural Network 
Setelah proses selesai, hasil identifikasi wajah yang berhijab akan dibuat menjadi katalog busana muslim dalam bentuk file pdf, output hasil identifikasi wajah berhijab dengan Convolutional Neural Network seperti pada gambar 13.

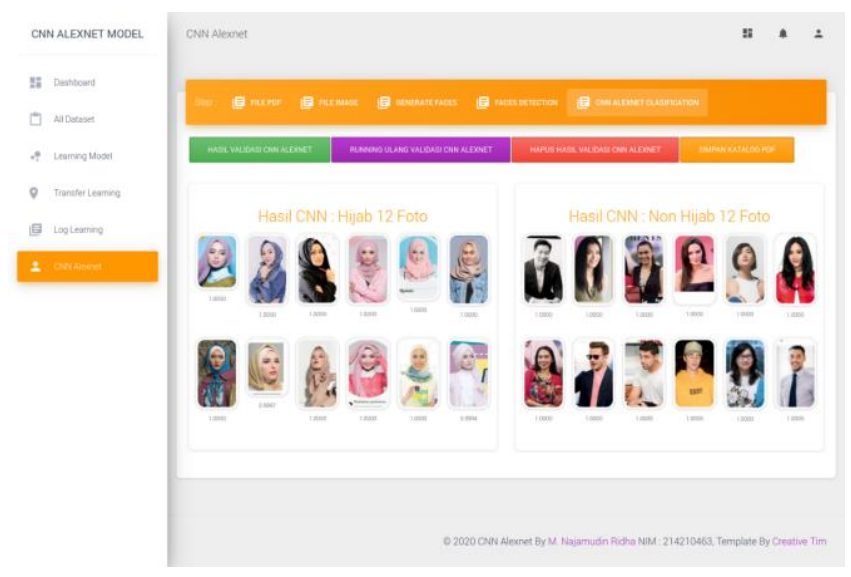

Gambar. 13. Output hasil identifikasi wanita berhijab atau tidak dengan Convolutional Neural Network

Setiap hasil identifikasi dari metode Convolutional Neural Network permajalah dihitung jumlah akurasi identifikasi wanita berhijab.

Proses perhitungan identifikasi dilakukan pada setiap model-model dengan paramter yang berbeda-beda untuk melihat model terbaik pada table $\mathrm{V}$ dan dengan data testing dengan resolusi 720p dan 1080p.

Untuk mempercepat proses akurasi, setiap output wajah yang terdeteksi dari metode Haar Cascades Classification, akan diklasifikasi terlebih dahulu wajah dengan hijab dan non hijab, kemudian akan dibandingkan dengan hasil klasifikasi menggunakan Convolutional Neural Network berdasarkan model-model yang telah di training. Hasilnya digunakan sebagai evaluasi data testing berdasarkan pada model dataset.

\section{Evaluasi Data Testing pada Model 2.500 Dataset}

Grafik perbandingan hasil akurasi rata-rata dataset 2.500 perkategori antara $720 \mathrm{p}$ dengan $1080 \mathrm{p}$ terhadap model data training dapat dilihat pada gambar 14 .

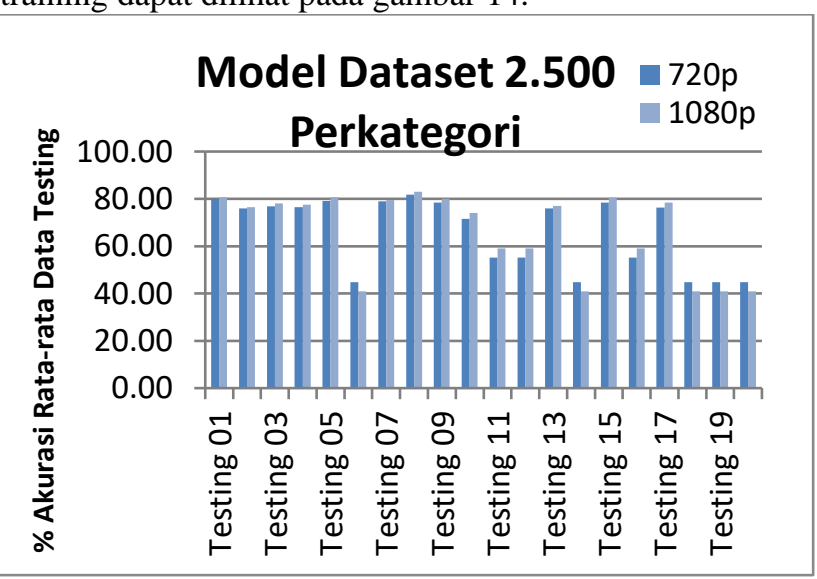

Gambar. 14. Grafik Perbandingan Rata-rata akurasi model dataset 2.500 terhadap majalah dengan resolusi 720 p dan 1080 p

2. Evaluasi Data Testing pada Model 2.500 Dataset Acak Grafik perbandingan hasil akurasi rata-rata dataset 2.500 Acak perkategori antara 720p dengan 1080p terhadap model data training dapat dilihat pada gambar 15 .

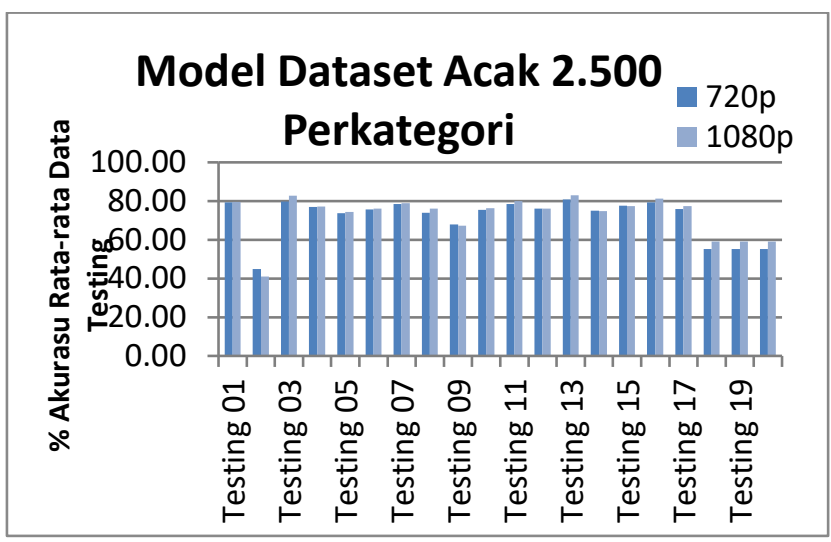

Gambar. 15. Grafik Perbandingan Rata-rata akurasi model dataset 2.500 acak terhadap majalah dengan resolusi $720 \mathrm{p}$ dan 1080p

\section{Evaluasi Data Testing pada Model 5.000 Dataset}

Grafik perbandingan hasil akurasi rata-rata dataset 5.000 perkategori antara 720p dengan 1080p terhadap model data training dapat dilihat pada gambar 16.

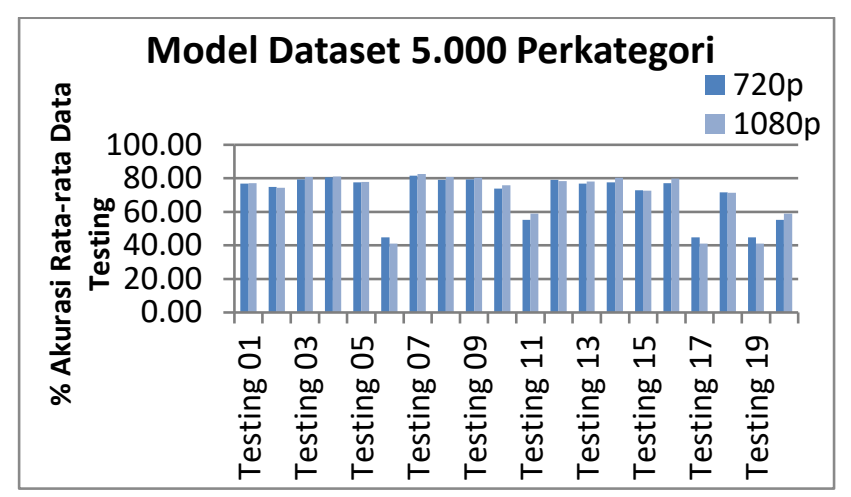

Gambar. 16. Grafik Perbandingan Rata-rata akurasi model dataset 5.000 terhadap majalah dengan resolusi 720 p dan 1080 p

\section{Evaluasi Data Testing pada Model 5.000 Dataset Acak}

Grafik perbandingan hasil akurasi rata-rata dataset 5.000 Acak perkategori antara 720p dengan 1080p terhadap model data training dapat dilihat pada gambar 17.

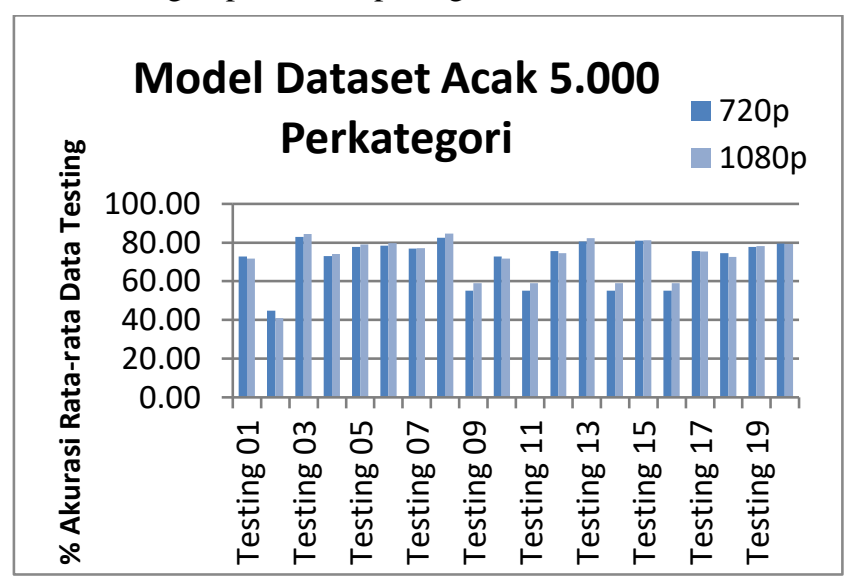

Gambar. 17. Grafik Perbandingan Rata-rata akurasi model dataset 5.000 Acak terhadap majalah dengan resolusi 720p dan 1080p

\section{E. Hasil Uji Coba Terbaik}

Setiap model yang digunakan untuk evaluasi data training menghasilkan nilai akurasi yang berbeda-beda berdasarkan data testing berupa majalah digital. Untuk akumulasi model yang terbaik dari data training sebelumnya adalah dengan 
menghitung rata-rata model yang digunakan terhadap majalah-majalah digital yang digunakan. Rata-rata akurasi model dikelompokkan berdasarkan resolusi data input majalah digital resolusi $720 \mathrm{p}$ dan majalah digital resolusi $1080 \mathrm{p}$

\section{Hasil Uji Coba Data Testing 720p}

Hasil uji coba model berdasarkan jenis data training dan kategori dataset yang terbaik untuk perangkat dengan resolusi data input $720 \mathrm{p}$ dengan kelompok testing semua majalah terdapat pada tabel VI.

TABEL VI

REKAP UJI COBA TERBAIK BERDASARKAN RESOLUSI 720P

\begin{tabular}{|c|c|c|c|c|c|}
\hline No & $\begin{array}{c}\text { Model } \\
\text { Dataset }\end{array}$ & Majalah & Model & $\begin{array}{c}\text { Avg Ac. } \\
\text { Majalah }\end{array}$ & $\begin{array}{c}\text { Avg Ac. } \\
\text { Model }\end{array}$ \\
\hline 1 & 2.500 & Majalah 03 & Testing 08 & $\mathbf{6 9 . 5 6 \%}$ & $\mathbf{8 1 . 8 1 \%}$ \\
\hline 2 & $\begin{array}{l}2.500 \\
\text { Acak }\end{array}$ & Majalah 04 & Testing 13 & $\mathbf{7 7 . 1 7 \%}$ & $\mathbf{8 0 . 7 9 \%}$ \\
\hline 3 & 5.000 & Majalah 03 & Testing 07 & $\mathbf{7 4 . 8 8 \%}$ & $\mathbf{8 1 . 6 8 \%}$ \\
\hline 4 & $\begin{array}{l}5.000 \\
\text { Acak }\end{array}$ & Majalah 03 & Testing 03 & $\mathbf{7 7 . 0 2 \%}$ & $\mathbf{8 2 . 9 3 \%}$ \\
\hline
\end{tabular}

Rekap ujicoba terbaik rata-rata berdasarkan resolusi 720 p terhadap semua majalah dan model

\section{Hasil Uji Coba Data Testing 1080p}

Hasil uji coba model berdasarkan jenis data training dan kategori dataset yang terbaik untuk perangkat dengan resolusi data input 1080p dengan kelompok testing semua majalah terdapat pada tabel VII.

TABEL VII

REKAP UJI COBA TERBAIK BERDASARKAN RESOLUSI 1080P

\begin{tabular}{|c|l|c|c|c|c|}
\hline No & $\begin{array}{c}\text { Model } \\
\text { Dataset }\end{array}$ & Majalah & Model & $\begin{array}{c}\text { Avg Ac. } \\
\text { Majalah }\end{array}$ & $\begin{array}{c}\text { Avg Ac. } \\
\text { Model }\end{array}$ \\
\hline 1 & 2.500 & $\begin{array}{c}\text { Majalah } \\
09\end{array}$ & $\begin{array}{c}\text { Testing } \\
08\end{array}$ & $69.13 \%$ & $83.06 \%$ \\
\hline 2 & $\begin{array}{l}2.500 \\
\text { Acak }\end{array}$ & $\begin{array}{c}\text { Majalah } \\
04\end{array}$ & $\begin{array}{c}\text { Testing } \\
13\end{array}$ & $77.35 \%$ & $82.99 \%$ \\
\hline 3 & 5.000 & $\begin{array}{c}\text { Majalah } \\
03\end{array}$ & $\begin{array}{c}\text { Testing } \\
07\end{array}$ & $73.96 \%$ & $82.63 \%$ \\
\hline 4 & $\begin{array}{l}5.000 \\
\text { Acak }\end{array}$ & $\begin{array}{c}\text { Majalah } \\
06\end{array}$ & $\begin{array}{c}\text { Testing } \\
08\end{array}$ & $77.11 \%$ & $84.72 \%$ \\
\hline
\end{tabular}

Rekap ujicoba terbaik rata-rata berdasarkan resolusi 1080p terhadap semua majalah dan model

Hasil Model terbaik adalah model data training dengan Dataset Acak 5.000 perkategori dan dengan parameter Batch Size 300 dan Epoch 100, menghasilkan rata-rata akurasi $84.72 \%$, sedangkan majalah dengan akurasi tertinggi adalah majalah 04 Joy Indonesia terbitan Oktober 2016 dengan akurati rata-rata adalah $77.35 \%$.

\section{KESIMPULAN}

Adapun Kesimpulan yang dapat diambil berdasarkan perancangan dan analisa sistem, preprocessing data training, preprocessing data testing, uji coba sistem dan evaluasi hasil berdasarkan model transfer learning, dapat disimpulkan halhal berikut ini:

1. Perbedaan Resolusi dataset majalah digital yang digunakan, mempengaruhi hasil wajah yang ditemukan menggunakan Haar Cascades Classification, yaitu terjadi peningkatan wajah ditemukan dari resolusi $720 \mathrm{p}$ ke 1080 p antara $20.62 \%$ sampai dengan $83.21 \%$ dengan rata-rata peningkatan pada setiap majalah sebesar $39.15 \%$.
2. Peningkatan wajah yang ditemukan dengan metode Haar Cascades Classification dari perbedaan resolusi mampu menemukan ukuran wajah yang kecil, namun tidak berpengaruh besar pada hasil akurasi identifikasi wajah dengan Convolutional Neural Network, terlihat peningkatan akurasi rata-rata dari perbedaan resolusi hanya sebesar $1.54 \%$.

3. Dengan peningkatan jumlah dataset untuk training dan validasi secara acak, mampu menambah hasil akurasi yang ditemukan, terjadi peningkatan akurasi pada dataset dari 2.500 wajah perkategori ke 5.000 wajah perkategori dengan resolusi 720p tertinggi sebesar $2.14 \%$ dan $1080 \mathrm{p}$ tertinggi sebesar $1.73 \%$. Akurasi tertinggi adalah pada model dengan 5.000 wajah perkategori dengan data training dan validasi secara acak, yaitu sebesar $84.72 \%$.

\section{DAFTAR PUSTAKA}

[1] I. W. S. E. Putra, "Klasifikasi Citra Menggunakan Convolutional Neural Network (Cnn) Pada Caltech 101,' J. Tek. ITS, vol. 5, no. 1, pp. 65-69, 2016, [Online]. Available: http://repository.its.ac.id/48842/.

[2] M. Alotaibi and A. Mahmood, "Improved gait recognition based on specialized deep convolutional neural network," Comput. Vis. Image Underst., vol. 164, pp. 103-110, 2017, doi: 10.1016/j.cviu.2017.10.004.

[3] M. Ghifary, “(Deep) Convolutional Neural Networks - Part 1,” 2015.

[4] D. Putra, Pengolahan Citra Digital. Yogyakarta: Penerbit Andi, 2010.

[5] M. T. . Hadi Pranoto, S.Kom, "Pengenalan Wajah: Teknik Mendeteksi Lokasi Wajah dalam Gambar dan Video," 2018.

[6] OpenCV, "About OpenCV.".

[7] M. M. Hanugra Aulia Sidharta, S.T, "Introduction To Open CV," 2017.

[8] R. Adam, "Apa Itu Google Colab," 2019. https://structilmy.com/2019/05/mengenal-google-colab (accessed Jan. 31, 2020).

[9] M. Syarif, P. Studi, T. Informatika, F. I. Komputer, U. Dian, and N Semarang, "Deteksi Kedipan Mata Dengan Haar Cascade Classifier Dan Contour Untuk Password Login," Techno.com, vol. 14, no. 4, pp. 242-249, 2015.

[10] S. K. Pavani, D. Delgado, and A. F. Frangi, "Haar-like features with optimally weighted rectangles for rapid object detection," Pattern Recognit., vol. 43, no. 1, pp. 160-172, 2010, doi: 10.1016/j.patcog.2009.05.011.

[11] N. Sofia, "Convolutional Neural Network." .

[12] U. S. Utara, U. S. Utara, and U. S. Utara, "Analisis Metode Backpropagation dengan Fungsi Aktivasi Sigmoid Bipolar dan Fungsi Linear dalam Prediksi Pertumbuhan Penduduk," 2019.

[13] S. Sena, "Pengenalan Deep Learning Part 7: Convolutional Neural Network (CNN)," 2018 https://medium.com/samuelsena/pengenalan-deep-lear.

[14] A. Sharifara, M. S. Mohd Rahim, and Y. Anisi, "A general review of human face detection including a study of neural networks and Haar feature-based cascade classifier in face detection," Proc. - 2014 Int. Symp. Biometrics Secur. Technol. ISBAST 2014, no. November 2016, pp. 73-78, 2015, doi: 10.1109/ISBAST.2014.7013097.

[15] H. Nguyen, S. J. Maclagan, T. D. Nguyen, and T. Nguyen, "Animal Recognition and Identification with Deep Convolutional Neural Networks for Automated Wildlife Monitoring," no. Figure 1, 2017, doi: 10.1109/DSAA.2017.31.

[16] N. Srinivas, H. Atwal, D. C. Rose, G. Mahalingam, K. Ricanek, and D. S. Bolme, "Age, Gender, and Fine-Grained Ethnicity Prediction Using Convolutional Neural Networks for the East Asian Face Dataset," Proc. - 12th IEEE Int. Conf. Autom. Face Gesture Recognition, FG 2017 1st Int. Work. Adapt. Shot Learn. Gesture Underst. Prod. ASL4GUP 2017, Biometrics Wild, Bwild 2017, Heteroge, pp. 953-960, 2017, doi: 10.1109/FG.2017.118.

[17] C. N. Networks, "Lecture 9: Understanding and Visualizing Convolutional Neural Networks Fei-Fei," Stanford Convolutional Neural Networks Vis. Recognit., pp. 1-83, 2016. 